\title{
Impact of familial amyloid associated polyneuropathy on duodenal endocrine cells
}

\author{
M El-Salhy, O Suhr, R Stenling, E Wilander, L Grimelius
}

\begin{abstract}
Duodenal endocrine cells in 11 patients with familial amyloid associated polyneuropathy (FAP) were compared with those in 12 healthy volunteers by means of immunohistochemistry and morphometry. The total endocrine cell content, determined by the argyrophilic reaction and chromogranin $A$ immunoreactivity, was significantly reduced in FAP patients compared with controls. There was a significant reduction in the serotonin, cholecystokinin/gastrin, and secretin immunoreactive cell content. A decreased cell content was also noted for somatostatin and gastric inhibitory polypeptide immunoreactive cells but this was not statistically significant. Amyloid deposits were noted in seven of the 11 biopsy specimens from FAP patients, but otherwise the duodenum was histologically normal in both groups. The reduction in endocrine cell content was not correlated with the degree of amyloid deposit in the duodenum. These findings indicate that patients with FAP have reduced intestinal endocrine cells. This does not seem to be related to amyloid deposits in the mucosa or to villous or crypt abnormalities. The observed changes in endocrine cells may contribute to the development of intestinal motility dysfunction and maldigestion in these patients.
\end{abstract}

(Gut 1994; 35: 1413-1418)

Amyloidosis represents a group of diseases characterised by the deposit of amyloid fibrils in various tissues. The protein precursor differs in various forms of amyloidosis. In several forms of familial amyloid polyneuropathy (FAP), mutated transthyretin (prealbumin) is the main fibril component. In Swedish FAP patients transthyretin is characterised by methionine at position $30\left(\mathrm{met}^{30}\right)$ instead of valine $^{1}$ as in FAP patients type I reported from Portugal $^{2}$ and Japan. ${ }^{3}$ FAP seems to occur throughout the world - cases have been reported in the USA, ${ }^{4}$ Ireland, ${ }^{5}$ China, ${ }^{6}$ Germany, ${ }^{7}$ France, Spain and Greece. ${ }^{8}$

In most patients, the initial clinical manifestation of FAP is a sensorimotor polyneuropathy starting in the legs and later affecting the arms. ${ }^{9}$ The autonomous nervous system is also affected, especially in more advanced stages of the disease. Symptoms include orthostatic hypotention, anhidrosis, sexual impotence, heart arrhythmia, and disturbance of gastrointestinal motility. ${ }^{9-11}$
Instances of severe constipation, sometimes accompanied by nausea and vomiting, are often the initial gastrointestinal symptoms. With time the constipation is relieved by bouts of diarrhoea that subsequently become continuous. ${ }^{1112}$

The course of the disease is steadily progressive, and life expectancy has been reported from Sweden to be approximately nine years from the onset of the symptoms. ${ }^{9}$ The cause of death is usually intercurrent infection and extreme malnutrition. ${ }^{11}$ As most transthyretin is produced by the liver, ${ }^{13}$ liver transplant has been performed, with encouraging results so far, on patients with FAP-met ${ }^{30}$ mutation and steadily progressive disease. ${ }^{13} 14$

Intestinal neuroendocrine peptides have a central role in the regulation of gastrointestinal motility, secretion, and ion transport. ${ }^{15-17}$ Several different modes of action have been described for these - that is, as paracrine/ endocrine hormones, neurotransmitters, and neuromodulators. ${ }^{18}$ Since severe gastrointestinal disturbance in both motility and absorption are common in FAP, it is possible that the neuroendocrine system is affected in these patients.

This study aimed to investigate the endocrine cells in the duodenum of FAP patients and to compare the findings with those in healthy controls. The duodenum was chosen because it contains a large number and variety of endocrine cells. ${ }^{19}$

\section{Methods}

\section{PATIENTS}

Duodenal biopsy specimens from 11 patients with FAP (seven men and four women; mean age 47 ; range $28-70$ years) were available for investigation. Nine patients had gastrointestinal symptoms (Table I). In all patients the diagnosis was based on the histological finding of amyloid deposits in skin or rectal mucosa, and electromyographical abnormalities consistent with peripheral polyneuropathy of the axonal type. In addition, the diagnosis was verified by DNA analysis ${ }^{20} 21$ for mutation of transthyretin in position 30 $\left(\mathrm{FAP}-\mathrm{met}^{30}\right)$. Clinical data were obtained from the patient's medical records and are summarised in Table I. Two patients were homozygous for the FAP-met ${ }^{30}$ gene.

Twelve healthy volunteers (six men and six women; mean age 39; range 22-71 years) who had given their written consent to the study served as controls. These volunteers had no gastrointestinal symptoms. The difference in 
TABLE I Clinical data of patients with familial amyloid associated polyneuropathy

\begin{tabular}{|c|c|c|c|c|c|c|c|c|}
\hline $\begin{array}{l}\text { Patient } \\
\text { no }\end{array}$ & Sex & $\begin{array}{l}\text { Age } \\
\text { (y) }\end{array}$ & $\begin{array}{l}\text { FAP } \\
\text { met } \\
\text { mutation }\end{array}$ & $\begin{array}{l}\text { Polyneuropathy } \\
\text { (y) }\end{array}$ & $\begin{array}{l}\text { Gastrointestinal } \\
\text { dysfunction } \\
\text { (y) }\end{array}$ & $\begin{array}{l}\text { Gastrointestinal } \\
\text { symptoms }\end{array}$ & $\begin{array}{l}\text { Autonomic nerve } \\
\text { dysfunction }\end{array}$ & Peripheral polyneuropathy \\
\hline 1 & $\mathbf{M}$ & 60 & Homoz & 9 & 7 & $\begin{array}{l}\text { Nausea, vomiting; intermit- } \\
\text { tent diarrhoea; sig- } \\
\text { moideostomy }\end{array}$ & $\begin{array}{l}\text { Urinary retention; uretheral } \\
\text { catheter }\end{array}$ & $\begin{array}{l}\text { Severely disabled, confined to } \\
\text { wheelchair }\end{array}$ \\
\hline 2 & $\mathbf{M}$ & 47 & Heteroz & 10 & 6 & Continuous diarrhoea; GEA & $\begin{array}{l}\text { Urinary hesitation; faecal incon- } \\
\text { tinence; autonomic heart dys- } \\
\text { function }\end{array}$ & $\begin{array}{l}\text { Walk short distances with two } \\
\text { crutches }\end{array}$ \\
\hline $3^{\star}$ & $\mathrm{F}$ & 43 & Heteroz & 6 & 5 & $\begin{array}{l}\text { Continuous diarrhoea; sig- } \\
\text { moideostomy; GEA }\end{array}$ & Urinary hesitation & $\begin{array}{l}\text { Walk short distances with two } \\
\text { crutches }\end{array}$ \\
\hline $\begin{array}{l}4 \dagger \\
5 \ddagger\end{array}$ & $\begin{array}{l}\mathrm{F} \\
\mathrm{M}\end{array}$ & $\begin{array}{l}47 \\
36\end{array}$ & $\begin{array}{l}\text { Heteroz } \\
\text { Heteroz }\end{array}$ & $\begin{array}{r}10 \\
5\end{array}$ & $\begin{array}{l}3 \\
5\end{array}$ & $\begin{array}{l}\text { Intermittent diarrhoea } \\
\text { Continuous diarrhoea }\end{array}$ & $\begin{array}{l}\text { Urinary hesitation } \\
\text { Urinary hesitation; faecal incon- } \\
\text { tinence }\end{array}$ & $\begin{array}{l}\text { Walk with one crutch } \\
\text { Confined to wheelchair }\end{array}$ \\
\hline 6 & $\mathbf{M}$ & 57 & Heteroz & 8 & 2 & $\begin{array}{l}\text { Intermittent diarrhoea; sig- } \\
\text { moideostomy }\end{array}$ & $\begin{array}{l}\text { Orthostatic hypotention; urinary } \\
\text { retention; uretral catheter }\end{array}$ & $\begin{array}{l}\text { Severely disabled; confined to } \\
\text { wheelchair }\end{array}$ \\
\hline 7 & $\mathbf{F}$ & 70 & Heteroz & 19 & 0 & None & None & $\begin{array}{l}\text { Walk short distances with two } \\
\text { crutches }\end{array}$ \\
\hline 8 & $\mathbf{M}$ & 42 & Heteroz & 7 & 3 & $\begin{array}{l}\text { Nausea, vomiting, continu- } \\
\text { ous diarrhoea }\end{array}$ & $\begin{array}{l}\text { Urinary hesitation; faecal incon- } \\
\text { tinence; autonomic heart dys- } \\
\text { function }\end{array}$ & Walk with two crutches \\
\hline 9 & $\mathbf{F}$ & 38 & Heteroz & 8 & 3 & Intermittent diarrhoea & $\begin{array}{l}\text { Faecal incontinence; autonomic } \\
\text { heart dysfunction }\end{array}$ & $\begin{array}{l}\text { Walk short distances with two } \\
\text { crutches; otherwise confined } \\
\text { to wheelchair }\end{array}$ \\
\hline $\begin{array}{l}10 \\
11\end{array}$ & $\begin{array}{l}\mathbf{M} \\
\mathbf{M}\end{array}$ & $\begin{array}{l}52 \\
28\end{array}$ & $\begin{array}{l}\text { Heteroz } \\
\text { Heteroz }\end{array}$ & $\begin{array}{l}1 \\
2\end{array}$ & $\begin{array}{l}0 \\
2 \text { Month }\end{array}$ & $\begin{array}{l}\text { None } \\
\text { Intermittent diarrhoea }\end{array}$ & $\begin{array}{l}\text { Autonomic heart dysfunction } \\
\text { Sexual impotence }\end{array}$ & $\begin{array}{l}\text { Sensory disturbances in the legs } \\
\text { Sensory disturbances in the legs }\end{array}$ \\
\hline
\end{tabular}

Homoz $=$ homozygous for FAP met $^{30}$ mutation; Heteroz=heterozygous. ${ }^{\star}$ Patient died aged 45 years; †died aged 52 years; $\ddagger$ died aged 39 years.

GEA = gastro-entero-anastomosis.

age between patients and controls was not statistically significant.

The investigation was approved by the local committee for medical ethics, at the University of Umeå.

UPPER GASTROINTESTINAL ENDOSCOPY Gastroduodenal endoscopic examinations were performed after an overnight fast. Endoscopic biopsy specimens were obtained from the pars descendens duodeni, distal to the papilla of Vater, either by means of a Watson biopsy capsule attached to the gastroscope or by biopsy forceps. The presence of solid residue in the stomach was recorded in the endoscopy reports, and regarded as an indication of gastric retention. Controls were subjected to an identical gastroduodenal endoscopic procedure.

\section{MATERIAL AND HISTOPATHOLOGICAL TECHNIQUE}

Biopsy specimens were fixed in $4 \%$ buffered formaldehyde overnight, embedded in paraffin, and cut at $5 \mu \mathrm{m}$. Sections from both patients and controls were stained with

TABLE II Detailed account of the antisera used

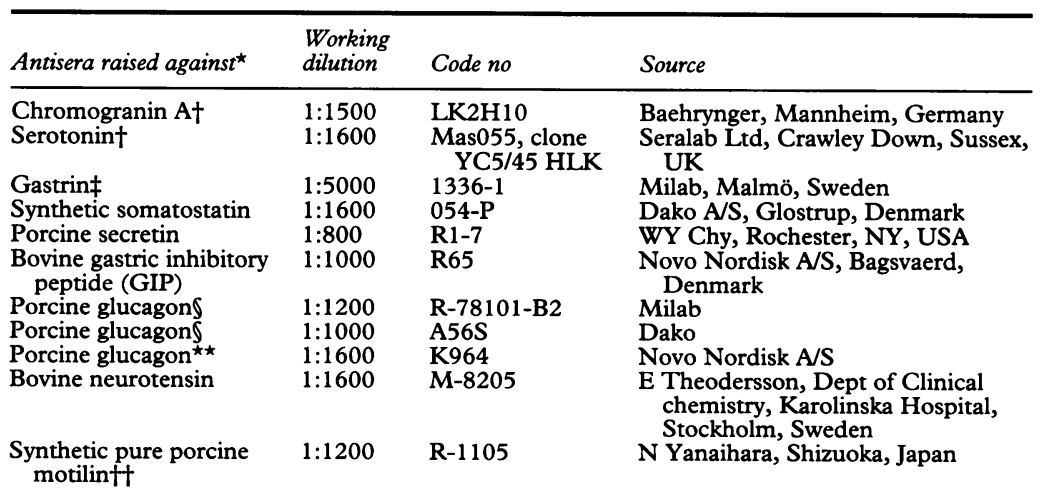

*All the antisera raised in rabbit except $\dagger$, which are monoclonal antibodies. $¥$ Specific for $\mathrm{CCK} /$ gastrin $\mathrm{C}$-terminus. \$Specific for glucagon $\mathrm{N}$-terminus and cross reacts with both pancreatic glucagon and entroglucagon. ${ }^{\star \star}$ Specific for glucagon $\mathrm{C}$-terminus reacts only with pancreatic glucagon. $+\dagger$ Specific for C-terminus. haematoxylin and eosin, van Gieson stain, and Grimelius's silver nitrate method. ${ }^{22}$ The presence of amyloid deposits was determined by polarisation microscopy of sections stained with alkaline Congo red.

\section{MORPHOMETRY}

\section{Mucosa}

A $10 \times 10 \mathrm{~mm}$ square grid (Zeiss) was inserted in a $\times 12.5$ eyepiece. The baseline of the grid was aligned with the base of the crypts in three sections cut perpendicular to the mucosa from each individual. The number of villi and crypts in an area $1 \mathrm{~mm}^{2}$ was counted using the $\times 10$ objective. The villus height was measured with a $1 \mathrm{~mm}$ scale inserted in a $\times 12.5$ eyepiece and a $\times 10$ objective.

\section{Amyloid deposits}

The amount of amyloid deposit was assessed by Haugh point count technique. ${ }^{23}$ Thus, a 121 point quadratic lattice (Zeiss, $10 \times 10 \mathrm{~mm}$, $19 \mathrm{~mm} \phi$, no 434008) was inserted in an $\times 12.5$ eyepiece. The lattice was aligned so that it covered the whole thickness of the mucosa, muscularis mucosa, and the part of submucosa available in each section. The number of amyloid deposits in the mucosa, muscularis mucosa, and submucosa situated at the grid points were counted, and at least 1000 points were counted in three sections from different levels of each biopsy specimen. Amyloid deposits were expressed as the percentage of the ratio between the number of points situated over amyloid deposits and the total number of grid points situated over the previously mentioned structures.

\section{NEUROENDOCRINE CELLS}

\section{Immunohistochemistry}

Each section was deparaffinised, hydrated, immersed in $0.01 \%$ hydrogen peroxide in Tris 
TABLE III Distribution and amount of amyloid deposition in biopsy specimens from pars descendens duodeni of FAP patients

\begin{tabular}{|c|c|c|c|c|c|c|c|}
\hline \multirow[b]{2}{*}{$\begin{array}{l}\text { Patient } \\
\text { no }\end{array}$} & \multicolumn{3}{|c|}{ Amyloid deposition } & \multirow{2}{*}{$\begin{array}{l}\text { Amyloid } \\
\text { deposit } \\
\text { (\% of } \\
\text { tissue) }\end{array}$} & \multirow{2}{*}{$\begin{array}{l}\text { Endocrine } \\
\text { cell area } \\
\left(\mu \mathrm{m}^{2} / \mathrm{mm}^{2}\right)^{\star}\end{array}$} & \multirow[b]{2}{*}{$\begin{array}{l}\text { Gastric } \\
\text { stasis }\end{array}$} & \multirow[b]{2}{*}{$\begin{array}{l}B M I \\
\left(\mathrm{~kg} / \mathrm{m}^{2}\right)\end{array}$} \\
\hline & Mucosa & $\begin{array}{l}\text { Musclaris } \\
\text { mucosa }\end{array}$ & Submucosa & & & & \\
\hline 1 & No & No & No & 0 & 25000 & Present & $18 \cdot 5$ \\
\hline 2 & No & No & No & 0 & 13000 & Present & 21.08 \\
\hline 3 & Yes & Yes & Yes & $7 \cdot 1$ & 325 & GEA & $15 \cdot 5$ \\
\hline 4 & Yes & Yes & Yes & $7 \cdot 1$ & 120 & Absent & $18 \cdot 3$ \\
\hline 5 & Yes & Yes & Yes & $8 \cdot 4$ & 1430 & Present & $15 \cdot 7$ \\
\hline 6 & No & No & No & 0 & 50 & Present & $21 \cdot 2$ \\
\hline 7 & No & No & No & 0 & 500 & Absent & 20.6 \\
\hline 8 & Yes & Yes & Yes & $34 \cdot 7$ & 8250 & Present & $19 \cdot 36$ \\
\hline 9 & Yes & Yes & Yes & $2 \cdot 7$ & 13140 & Present & $20 \cdot 1$ \\
\hline 10 & Yes & Yes & Yes & $8 \cdot 5$ & 15280 & Absent & $23 \cdot 7$ \\
\hline 11 & Yes & Yes & Yes & $5 \cdot 5$ & 9240 & Absent & NA \\
\hline
\end{tabular}

^Endocrine cell area as detected by the argyrophilic reaction, expressed as $\mu \mathrm{m}^{2} / \mathrm{mm}^{2}$ of epithelial cells (controls: mean $(S D)=14870(4710)$ ). $B M I=$ body mass index. †Patients with nephrotic syndrome and oedema. $\mathrm{NA}=$ not available.

$\mathrm{HCl}$ buffer (pH 7.4) for 10 minutes to inhibit endogenous peroxidase activity, washed three times with TRIS buffer, and treated with $1 \%$ bovine serum albumin for 30 minutes. Incubation took place overnight with the following antisera: anti-chromogranin $\mathrm{A}$, anti-serotonin, anti-gastrin, anti-somatostatin, anti-secretin, anti-gastric inhibitory polypeptide (GIP), anti-glucagon, anti-neurotensin, and anti-motilin (for details concerning the antisera used see Table II). The sections were then processed by the avidin-biotin complex method (ABC, Dako A/S, Glostrup, Denmark). Briefly, sections were incubated with biotinyated swine anti-rabbit IgG or biontinyated anti-mouse IgG diluted 1:200 for 30 minutes. They were then incubated with the avidin-biotin-peroxidase complex diluted 1:100 for 30 minutes. Development of the section was performed in $50 \mathrm{ml}$ Tris buffer containing $10 \mu \mathrm{l}$ of $30 \%$ $\mathrm{H}_{2} \quad \mathrm{O}_{2}$ and $25 \mathrm{mg}$ diaminobenzidin-hydrochloride (DAB).

The specificity controls were similar to those described previously. ${ }^{24}$ Briefly, negative controls were obtained by using normal rabbit serum (Tris buffer in case of monoclonal antibodies) in place of the primary antiserum and by preincubating antiserum with an excess of

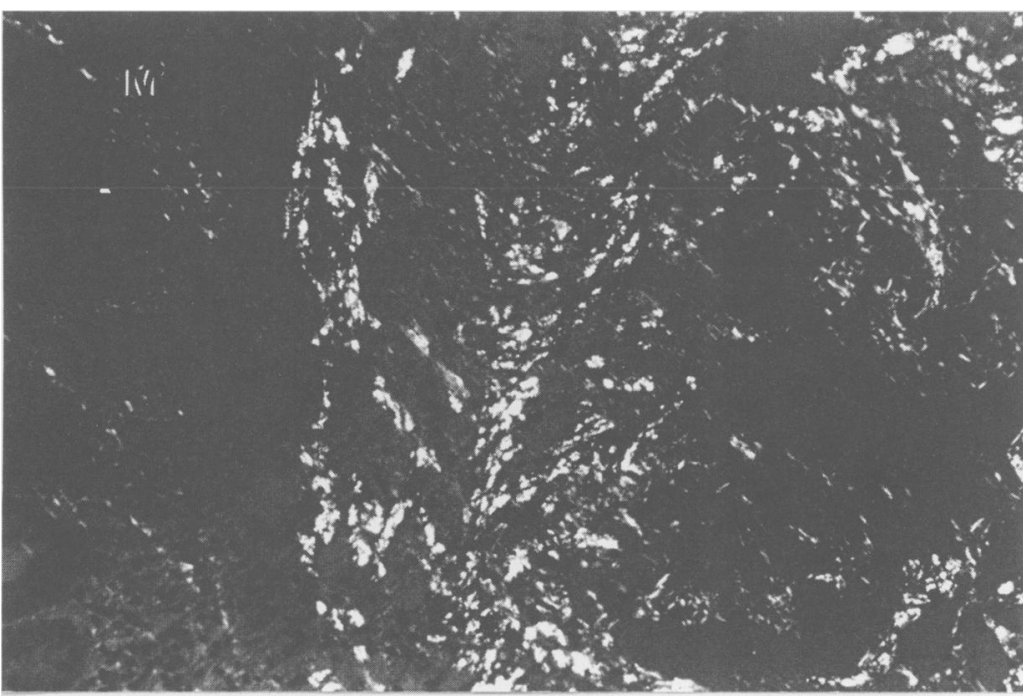

Figure 1: Amyloid deposits in the pars descendens duodeni of a FAP patient. The deposits look green (white in the photomicrograph) when examined in polarised light. The deposits can be seen in the mucosa (M), muscularis mucosa (MM), and submucosa (SM). (Alkaline Congo red stain, $\times 150$.) the corresponding or structurally related antigen $(75-100 \mu \mathrm{g} / \mathrm{ml}$ diluted antiserum) for 24 hours at $4^{\circ} \mathrm{C}$. Positive controls were obtained by processing sections known to contain the neuroendocrine peptide studied with each staining experiment.

\section{Morphometry}

This was performed by the IBAS-Micro version 2.0 program, using the IBAS automatic image analysis system (Kontron Electronic, Munich, Germany) connected to a Carl Zeiss microscope, type axiophot. The epithelial cell area was determined by two threshold levels. To discriminate between epithelial cells (including endocrine cells) and background and lamnia propria, the upper limit and lower limit were determined by interactive setting. This was performed by moving the cursor on the tablet to the $\mathrm{X}$ and $\mathrm{Y}$ positions. The cursor key \#5 was pressed once to freeze the lower threshold and again to freeze the upper threshold. The endocrine cell area was estimated by using the interactive image editor, which erased the outside region. This was done by drawing a continuous line around the endocrine cells contour and erasing outside structures. For each endocrine cell type, 40 randomly chosen fields of villous and crypts from four sections, $30 \mu \mathrm{m}$ apart, were used from each individual. Each field seen in the monitor represents $0.16 \mathrm{~mm}^{2}$ of tissue. The quantity of endocrine cells was expressed as $\mu \mathrm{m}^{2} / \mathrm{mm}^{2}$ of the lining epithelium. Sections were coded and the investigator who performed the measurements, did not have the code key. All measurements were performed by one investigator (ME).

\section{STATISTICAL ANALYSIS}

Differences between groups were analysed by means of the Wilcoxon rank sum test; correlation was determined by Spearman's rank test. p Values below 0.05 were regarded as statistically significant.

\section{Results}

\section{ENDOSCOPY}

The presence of solid residue in the stomach was reported in seven of the FAP patients but in none of the healthy controls. All patients with gastric stasis had gastrointestinal symptoms, whereas one without this had intermittent constipation and diarrhoea (Tables I and III).

\section{HISTOPATHOLOGICAL EXAMINATION}

Histopathological examination of specimens from FAP patients and healthy controls showed a normal histological structure. The average number of villi in FAP patients was $3.5 / \mathrm{mm}^{2}$ (range, 3-4) and in controls $3 \cdot 7 / \mathrm{mm}^{2}$ (range, 3-5). The average number of crypts in FAP patients was $8 / \mathrm{mm}^{2}$ (range, $6-10$ ) and in 

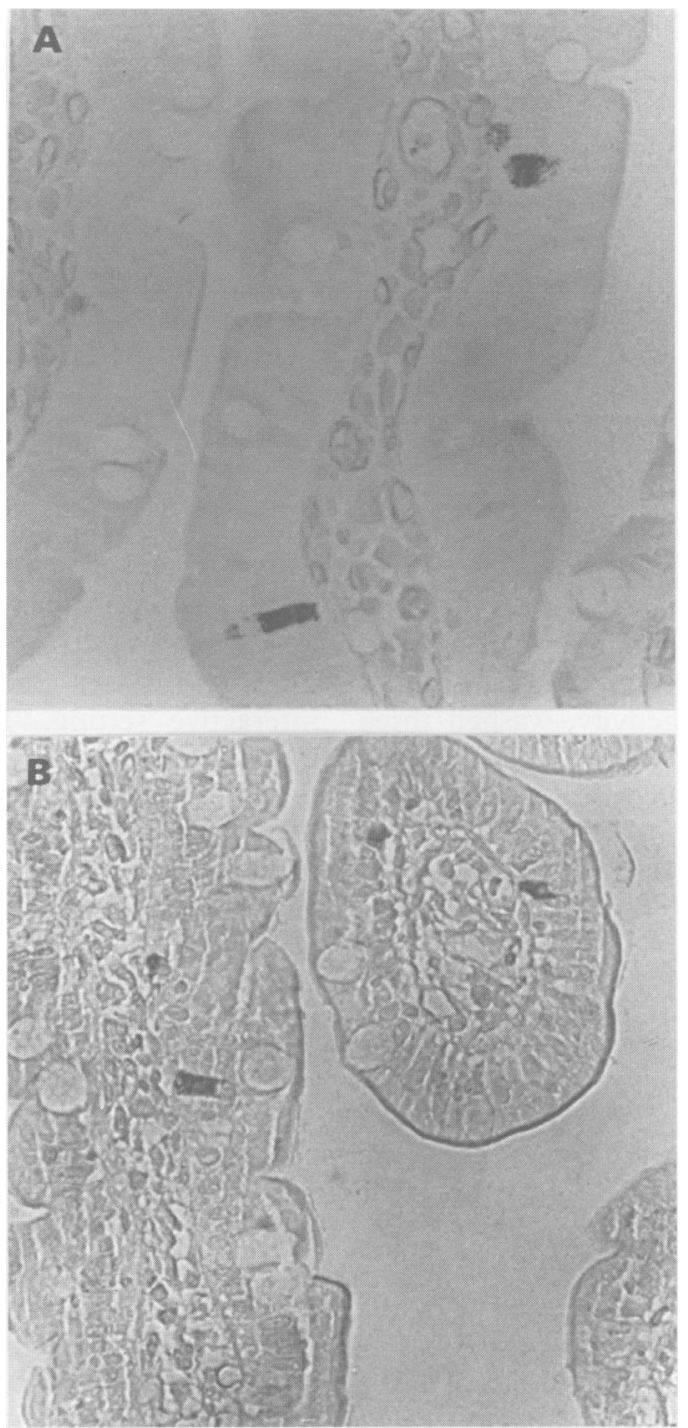

Figure 2: Argyrophil cells in the villous of a healthy contro (A) and of a FAP patient (B). (Grimelius stain, $\times 450$.)

controls it was $7 \cdot 5 / \mathrm{mm}^{2}$ (range, $7-10$ ). The average height of the villi in FAP patients was $0.9 \mathrm{~mm}$ (range, $0.8-1$ ) and in controls this was $0.9 \mathrm{~mm}$ (range, $0 \cdot 7-1 \cdot 1$ ). No significant differences were found between patients and controls with regard to the numbers of villi, crypts, or the villous height. Amyloid deposits were noted in seven specimens from FAP patients (Fig 1), details of the localisation and quantity of these deposits are given in Table III. No correlation was found between the degree of amyloid deposition in the duodenum and the duration of disease.

\section{ENDOCRINE CELLS}

Argyrophilic (Fig 2), chromogranin A, serotonin (Fig 3), cholecystokinin (CCK)/gastrin C-terminus, somatostatin (Fig 4), secretin, and GIP immunoreactive cells were observed in the pars descendens duodeni of both FAP patients and controls. Argyrophilic, chromogranin A, and serotonin immunoreactive cells were found in both the villi and crypts. $\mathrm{CCK} / g a s t r i n$ and secretin immunoreactive cells were confined almost to the villous epithelium. Somatostatin, and GIP immunoreactive cells were mainly localised within crypts. Glucagon, neurotensin, and motilin immunoreactive cells were not detected in either controls or FAP patients.

Specificity controls showed that the antisera immunostained endocrine cells in the small intestine of the rats. Immunostaining was abolished completely after preincubation with the corresponding peptide. Preincubation of the antisera with the structurally related peptides had no effect on the immunostaining. Replacing the antisera with normal rabbit serum or Tris buffer gave no staining.

The endocrine cell content, as demonstrated by argyrophilic cells and chromogranin A immunoreactive cells, was significantly reduced in FAP patients compared with controls $(p<0.01$ and 0.001 respectively). There were significantly fewer serotonin, CCK/gastrin, and secretin immunoreactive cells in FAP patients compared with controls ( $<<0.01,0.05$, and 0.001 respectively). Decreased cell contents, which were not statistically significant, were noted for somatostatin and GIP immunoreactive cells (Table IV). No significant correlation was found between age and endocrine cell content, either for patients or controls. No correlation was found between the body mass index (BMI) and the endocrine cell content (Table III). No significant correlation was found between the total endocrine cell content and the presence or the degree of the amyloid deposits.

\section{Discussion}

Gastrointestinal absorption, secretion, coordinated peristalsis, blood flow, and the
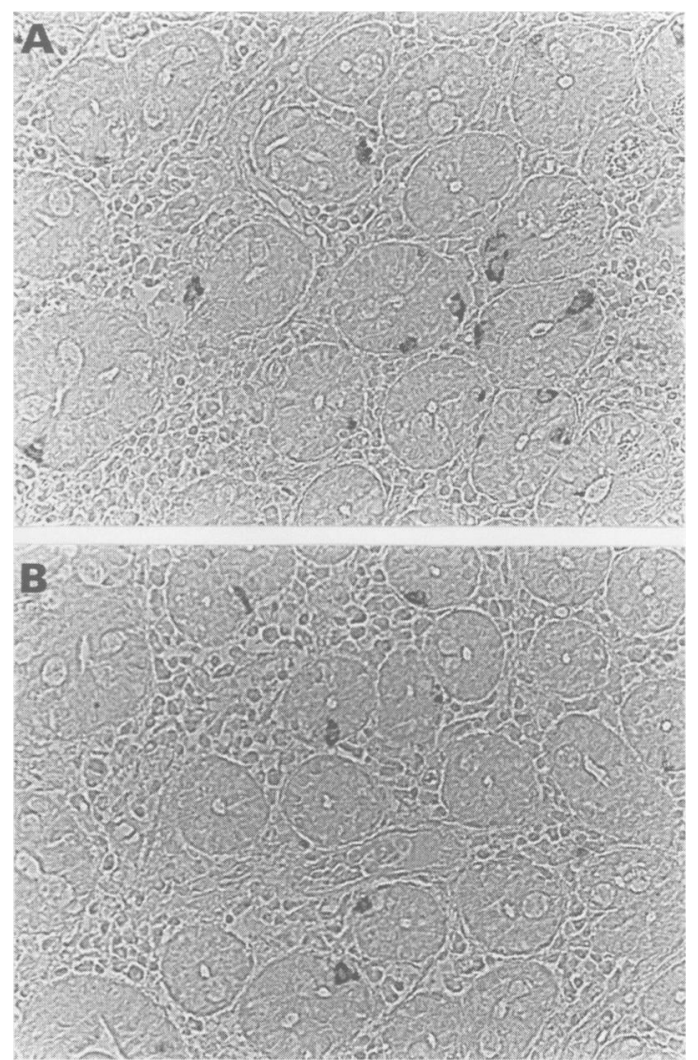

Figure 3: Serotonin immunoreactive cells in the crypts of a healthy control $(A)$ and of a FAP patient (B). ( $A B C$ technique without counterstaining, $\times 150$. 


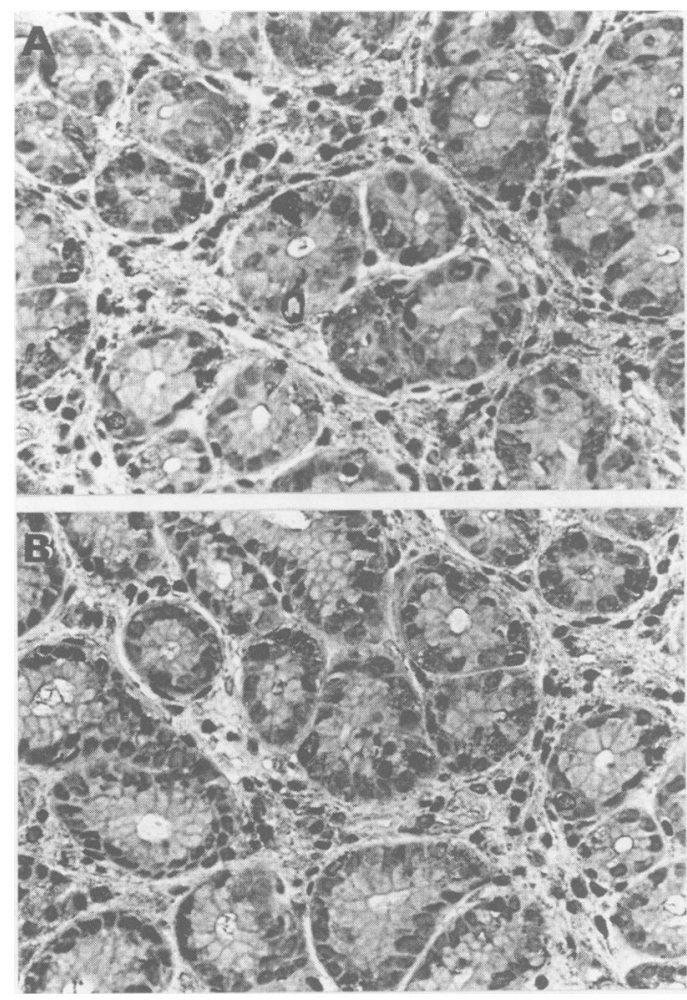

Figure 4: Somatostatin immunoreactive cells in the crypts of a healthy control $(A)$ and of a FAP patient $(B)$. (ABC technique and counterstained with haematoxylin, $\times 350$.)

immune response are regulated by nervous and endocrine/paracrine mechanisms. ${ }^{15} 16$ The nervous control is exerted by central 'extrinsic' (parasympathetic, sympathetic, and sensory) as well as by local 'intrinsic' neurons. ${ }^{16}$ The degree of extrinsic control varies between different parts of the gastrointestinal tract. Thus, the parasympathetic system seems to control the motor activity of the oesophagus and stomach as well as the gastric secretion, but has no influence on the intestinal functions. ${ }^{16}$ Sympathetic innervation inhibits intestinal secretion, gut motility, and blood flow. The intrinsic innervation represents the majority of the nervous elements in gastrointestinal tract with the neuropeptides as the predominating neurotransmitters. ${ }^{16}$

The peptidergic neurons act as motor, vasomotor, secretory, or sensory neurons. ${ }^{15}$ Several peptides of the intrinsic nervous system regulate the intestinal motility. Thus, substance $P$ has a contractile effect and neuropeptide Y (NPY), vasoactive intestinal polypeptide (VIP), and galanin have a relaxing effect on the intestinal smooth muscles. ${ }^{16}$ The endocrine/paracrine regulatory system is composed of scattered cells among the epithelial cells of the mucosa. These cells are divided into 11 cell types depending on the peptide or biogenic amine they contain, as follows: secretin, gastrin, CCK, GIP, somatostatin, enteroglucagon, neurotensin, PP, PYY, motilin, and serotonin. ${ }^{19} 2526$ These cell types have a special pattern of distribution in the gastrointestinal tract, which has a certain bearing on their functions. Thus, serotonin and somatostatin cells occur throughout the gut. Gastrin cells occur only in stomach. CCK, secretin, enteroglucagon, neurotensin PP, and PYY cells are found in the small intestine. Enteroglucagon, PP, and PYY cells are located in the large intestine. ${ }^{192526}$

It is noteworthy that the endocrine cells have several peptides/biogenic amines in common with peptidergic nervous system namely, somatostatin, gastrin/CCK, neurotensin, and serotonin. These cells exert their effect through secretion of their peptides into the blood stream (endocrine function) to be carried to the target organ or into the interstitial fluid (paracrine function) to diffuse to their site of action. ${ }^{19}$ Both the nervous and endocrine/paracrine regulating systems interact and integrate in regulating the previously mentioned functions of the gastrointestinal tract. $^{15}$

In FAP patients abnormalities in the extrinsic and the classical part of the intrinsic innervation of the gut have been observed. Thus, amyloid infiltration and severe loss of myelinated nerve fibres in the celiac ganglion and vagus nerve have been found in FAP patients. ${ }^{27}$ Furthermore, low level of catecholamines have been reported in familial amyloid intestine. ${ }^{28} 29$ Changes in the peptidergic nerve system in these patients are unknown. This is due to the difficulty in obtaining whole wall biopsy specimens from FAP patients, as their condition never calls for surgery.

In this study both the argyrophilic reaction and chromogranin A immunoreactivity were used as markers for the total number of endocrine cells, according to previous recommendations. ${ }^{30}$ The endocrine cell content was significantly low in FAP patients compared with healthy controls. Of the endocrine cell types analysed, the serotonin, CCK/gastrin, and secretin immunoreactive cells were significantly reduced. It has been established

TABLE IV Mean (SD) area of crypt and villous epithelium occupied by endocrine cell types in FAP patients and healthy controls

\begin{tabular}{|c|c|c|c|c|c|c|c|c|}
\hline \multirow[b]{2}{*}{ Cell type } & \multicolumn{4}{|l|}{$F A P$ patients } & \multicolumn{4}{|l|}{ Controls } \\
\hline & Crypt & Villous & Total & No & Crypt & Villous & Total & No \\
\hline $\begin{array}{l}\text { Argyrophil } \\
\text { Chromogranin A } \\
\text { Serotonin } \\
\text { CCK/gastrin } \\
\text { Somatostatin } \\
\text { Secretin } \\
\text { GIP }\end{array}$ & $\begin{array}{c}8404(8698) \dagger \\
6714(5421)^{\star} \\
5452(7883) \ddagger \\
0 \\
1625(1817) \\
0 \\
1817(2705)\end{array}$ & $\begin{array}{c}4270(6146) \\
4460(5068) \ddagger \\
2014(3021) \dagger \\
507(973) \ddagger \\
0 \\
186(467) \star \\
0\end{array}$ & $\begin{array}{l}7904(8276) \ddagger \\
5585(4837)^{\star} \\
4064(5382) \dagger\end{array}$ & $\begin{array}{l}11 \\
11 \\
10 \\
10 \\
10 \\
11 \\
11\end{array}$ & $\begin{array}{c}21212(7984) \\
22132(9410) \\
14209(6885) \\
0 \\
3581(1706) \\
0 \\
3492(2072)\end{array}$ & $\begin{array}{c}7395(5009) \\
11939(9492) \\
10187(8178) \\
3943(2738) \\
0 \\
5955(4500) \\
0\end{array}$ & $\begin{array}{l}14870(4705) \\
17361(4369) \\
12765(6389)\end{array}$ & $\begin{array}{r}11 \\
12 \\
10 \\
11 \\
10 \\
11 \\
9\end{array}$ \\
\hline
\end{tabular}

Endocrine cell area expressed as $\mu \mathrm{m}^{2} / \mathrm{mm}^{2}$ of epithelial cell area. Statistically different between FAP patients and controls; ${ }^{\star} \mathrm{p}<0.001 ; \mathrm{tp}<0.01 ; \neq \mathrm{p}<0.05$. GIP= gastric inhibitory peptide; $\mathrm{CCK}=$ cholecystokinin; total=total endocrine cell area in crypt and villous epithelium. 
that serotonin exerts both direct and indirect excitatory effects on the gut smooth muscles, where indirect effects are mediated by the cholinergic nerves. CCK has a stimulatory effect on antral and pyloric contraction and an inhibitory effect on the proximal stomach. ${ }^{16} 18$ In the small intestine, CCK initiates peristaltic activity and increases the efficiency of the peristaltic reflex. ${ }^{18}$ The reduction in these cells in FAP patients may lead to impairment of intestinal motility and the development of gastric stasis, promoting bacterial contamination and malabsorption. ${ }^{71112} \mathrm{CCK}$ and secretin stimulate the pancreatic secretion of enzymes and bicarbonates. The significant reduction observed in the area of these cells may contribute to the development of maldigestion and steatorrhoea. ${ }^{11} 12$

The reduction in endocrine cells did not correlate with the presence or the degree of the amyloid depositions. In addition, the villous and crypt structure of amyloid and healthy intestine was histologically similar. These findings indicate that the reduction in the endocrine cell area in FAP patients is not caused by amyloid deposits in the mucosa or villous and crypt changes.

Further studies are needed to establish whether the decrease in the endocrine cells observed here in patients with amyloid associated neuropathy is associated with decreased secretion of these hormones. This can be done by determination of the hormonal level in tissue extracts or counting the secretory granules in electron micrographs, or both. Furthermore, it could be of great value to correlate these findings to the abnormal gastrointestinal motility shown in FAP patients by different motility tests.

This study was supported by grants from the Swedish Medical Research Council (projects no 102 and 11240), the Åke Wibergs Stiftelse, the Medical Faculty, Umeå University, the Joint Committee for Medical Research, Northern Health Region, and the Swedish Medical Association.

Preliminary results were presented in abstract form in Preliminary results were presented in abstract form in
the 2nd International Symposium on Familial Amyloidtic the 2nd International Symposium on Familial Amyloidtic Polyneuropathy and Other Transthyretin Related Disorders,
held in Skelleftå, Sweden, from 1-3 June 1992; and in the first International Workshop on Modern Analytical Methods in Histochemistry, held in Salzburg, Austria, from 14-18 September 1992 .

1 Holmgren G, Haettner E, Nordenson I, Sandgren O, Steen $L$, Lundgren E. Homozygosity for the transthyretinmet $^{30}$-gene in two Swedish sibs with familial amyloidoitic polyneuropathy. Clin Genet 1988; 23: 333-8.

2 Saraiva M, Costa P, Burken S, Goodman D. Preschooler of an abnormal transthyretin in Portuguese patients with amyloidotic polyneuropathy. Trans Assoc Am Physicians 1983; 96: 261-70.

3 Tawara S, Nakazato M, Kanagawa K, Matsuo, H, Akari S. Identification of amyloid prealbumin variant in familial amyloidtic polyneuropathy (Japanese type). Biochem Biophys Res Comm 1983; 116: 880-8.

4 Dwulet F, Benson M, Polymorphism of human plasma thyroxin binding prealbumin. Biochem Biophys Res Commun 1983; 114: 657-62.

5 Staunton H, Dervan P, Kale R, Linke RP, Kelly P.
Hereditary amyloid polyneuropathy in north west Ireland. Brain 1987; 110: 1231-45.

6 Chang CM, Yu Yl, Wong M, NG TH, Woo E, Haung CY. Type I familial amyloid polyneuropathy in Chinese family. Acta Neurol Scand 1989; 79: 391-6.

7 Feurle G. Pathophysiology of diarrhea in patients with familial amyloid neuropathy. Digestion 1987; 36: 13-7.

8 Holt IJ, Harding AE, Middletton L, Chrysostomou G, Said G, King RH, et al. Molecular genetics of amyloid $\Omega$ neuropathy in Europe. Lancet 1989; i: 524-6.

9 Andersson R. Familial amyloidosis with polyneuropathy: A clinical study based on patients living in northern Sweden. Acta Medica Scandinavica 1976; 198 (suppl 590); $1-64$.

10 Olofsson B-O. Cardiac involvement in familial amyloidosis with polyneuropathy. Int $\mathcal{f}$ Cardiol 1983; 4: 71-3.

11 Steen L, Ek B. Familial amyloidosis with polyneuropathy. A $\frac{\mathcal{W}}{\partial}$ long term follow up of 21 patients with special reference to $\mathbb{D}$ gastrointestinal symptoms. Acta Medica Scandinavica

12 Suhr O, Danielsson A, Steen L. Bile acid malabsorption $\stackrel{\leftrightarrow}{\rightarrow}$ caused by gastrointestinal motility dysfunction? An $\overrightarrow{0}$ investigation of patients with familial amyloidosis with polyneuropathy. Scand $f$ Gastroenterol 1992; 27: $\vec{\omega}$

3 Holmgren G, Steen L, Ekstedt J, Groth C-G, Ericksson B-G, Eriksson S, et al. Biochemical effect of liver transplantation in two Swedish patients with familial amyloidotic polyneuropathy (FAP-met $\left.{ }^{30}\right)$. Clin Genet of 1991; 40: 242-6.

14 Holmgren G, Ericksson B-G, Groth C-G, Suhr O, Steen L, Andersson $\mathrm{O}$, et al. Clinical benefit and regression of $\vec{A}$ amyloidosis following liver transplantation in patients $\vec{A}$ with familial amyloid polyneuropathy due to transthyretin $\vec{\omega}$ with familial amyloid polyneuropathy due to

15 Debas Th, Mulvihill SJ. Neuroendocrine design of the gut. Am F Surg 1991; 161: 243-9.

16 Ekblade E, Håkansson R, Sundler F. Microanatomy and $O$ chemical coding of peptides-containing neuron in the digestive tract. In: Daniel E, ed. Neuropeptides function in $\bar{O}$ gastrointestinal tract. Boston, Ann Arbor: CRC Press; INC $\mathbb{D}$ Boca Rotor, 1991: 131-80.

17 Harvey RF. Hormonal control of gastrointestinal motility. $\vec{\theta}$ Am $\mathcal{F}$ Dig Dis 1975; 20: 523-39.

18 Allescher $H$, Ahmed $S$. Postulated physiological and $\$$ pathophysiological roles on motility. In: Daniel E, ed. Neuropeptides function in gastrointestinal tract. Boston, Ann Arbor: CRC Press; INC Boca Rotor, 1991: 309-400.

19 Sjölund K, Sandén G, Håkanson R, Sundler F. Endocrine cells in human intestine. An immunocytochemical study. Gastroenterology 1983; 85: 1120-30.

20 Southern E. Detection of specific sequences among DNA fragments separated by gel electrophoresis. $\mathrm{f}$ Mol Biol $\overline{\mathrm{O}}$ 1975; 98: 503-17.

21 Holmgren G, Holmberg E, Lindstrom A, Lindstrom E, Nordenson I, Sandgren O, et al. Diagnosis of familial amyloidotic polyneuropathy in Sweden by RFLP analysis. amyloidotic polyneuropathy in

22 Grimelius L, Wilander E. Silver stains in the study of endocrine cells of the gut and pancreas. Investigative Cell Pathology 1980; 3: 3-12.

23 Weibel ER. Principles and methods for morphometric 3 study of the lung and other organs. Lab Invest 1963; 12:

24 El-Salhy M, Wilander E, Lindqvist M, Nilsson G, Moody A, Imawaga $\mathrm{K}$, et al. Glucagon and glucagon-like $\mathrm{O}$ immunoreactive cells in mid- and hind-gut carcinoids. APMIS 1988; 96: 537-42.

25 Buchan A, Polak JM. The classification of the human gastroenteropancreatic endocrine cells. Investigative Cell Pathology 1980; 3: 51-71.

26 El-Salhy M, Grimelius L, Wilander E, Ryberg B, Terenius of $\mathrm{L}$, Lundberg JM, et al. Immunocytochemical identi- $N$ fication of polypeptide YY (PYY) cells in the human gastrointestinal tract. Histochemistry 1983; 77: 15-23.

27 Ikeda S, Yanagisawa N, Hongo M, Ito N. Vagus nerve and $\sigma$ celiac ganglion lesions in generalized amyloidosis. A $<$ correlative study of familial amyloid polyneuropathy and $Q$ AL-amyloidosis. F Neurol Sci 1987; 79: 129-39.

28 Hofer P- $\AA$, Andersson R. Postmortem findings in familial $\&$ amyloidosis with polyneuropathy: a study based on six cases from northern Sweden. Acta Pathologica et Microbiologica Scandinavica $(A)$ 1975; 83: 309-22.

29 Rubenstein A, Yahr M, Mytileneou C, Bajaj K. Peripheral cathecholamin depletion in amyloid autonomic neuropathy. M Sinai F Med 1978; 45: 782-9.

pathy. M Sinai f Med 1978; 45: 782-9.

Geting Y. Chromogranin A immunoreactivity and endocrine cells. Anat Embryol (Berl) 1992; 185: 207-15. 